
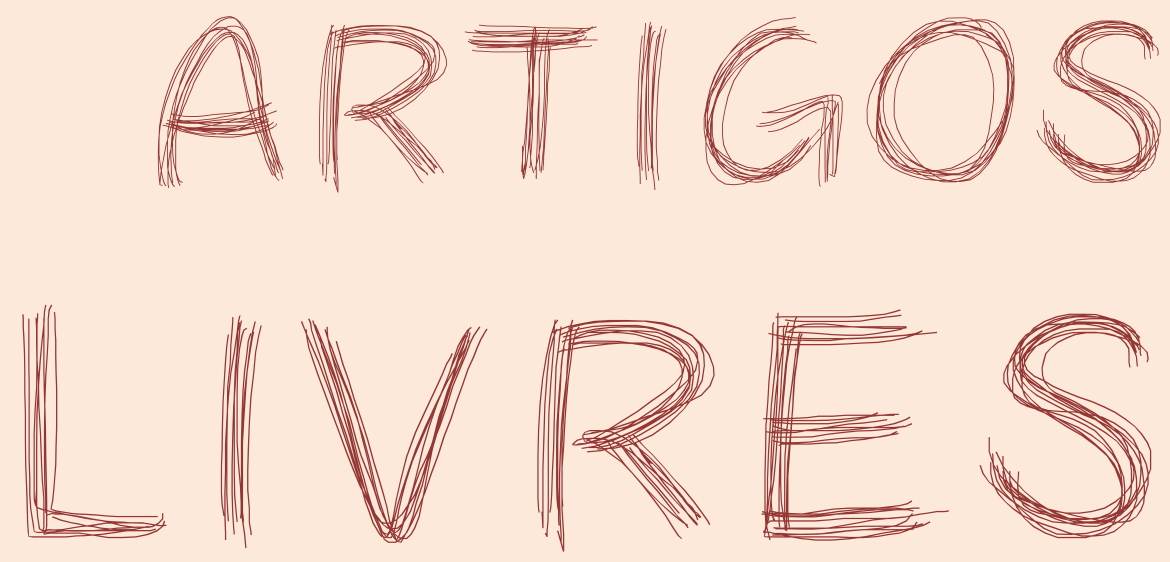


\section{BOCA DE CANTAR, CANTO DE GRITAR: VIOLÊNCIA, RACIALIZAÇÃO E JUVENTUDE.}

Ari Madeira Costa

Mestrando do Progama de Pós-Graduação em Educação do Campus Universitário de Rondonópolis da Universidade Federal de Mato Grosso.

ari.costa@mpmt.mp.br

resumo: Pretende-se mostrar no presente ensaio algumas faces do apagamento moral e do extermínio de jovens negros na cidade de Rondonópolis/MT. Com efeito, existe urgência em se assegurar aos jovens brasileiros uma existência digna, bem como maneiras de inserção na economia do Estado. Entretanto, em que pese a prioridade absoluta assegurada pela Constituição e pelas leis em favor dos direitos da juventude, as políticas públicas não tem sido eficazes em tal mister, notadamente, quando está em jogo a incolumidade física e moral daqueles que mais têm pressa em ver extirpadas da sociedade as práticas de extermínio do diferente.

palauras-chave: Juventude; políticas públicas; sociedade. abstract: This essay intends to show some faces of the moral erasure and extermination of young blacks in the city of Rondonópolis/MT. In fact, there is an urgent need to ensure that young Brazilians have a dignified existence, as well as ways of insertion into the state economy. However, in spite of the absolute priority given by the Constitution and the laws in favor of the rights of the youth, public policies have not been effective in this respect, especially when it is at stake the physical and moral safety of those who are most in a hurry to see extirpated from society the practices of extermination of the different.

key-words: Young; public policy; society. 
Mas mesmo assim

Ainda guardo o direito

De algum antepassado da cor

Brigar sutilmente por respeito

De algum antepassado da cor

Brigar bravamente por respeito

De algum antepassado da cor

Brigar por justiça e por respeito

De algum antepassado da cor

Brigar, brigar, brigar

A Carne-- Marcelo Yuka,

Ulisses Cappelletti, Seu Jorge

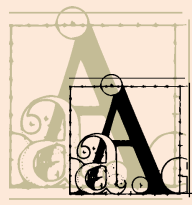

nda agora e de uma só vez, aviso que me permiti o devaneio e a aventura de inserir, em alguma medida, um fundo poético no corpo do presente texto, eis que a poesia me constitui principalmente naquilo que não sei dizer e nas dores muitas que não gritei.

Desde muito cedo, fui alguém muito curioso. Quando criança, entre os vários questionamentos solitários e sem eco que fazia, eu queria saber o que aconteceria comigo depois que eu morresse e, na falta de alguém que me levasse a sério, na falta de alguém que não se incomodasse depois de minha segunda pergunta, acreditava que meus últimos passos, minhas derradeiras ações permaneceriam como um pêndulo, repetindo-se eternamente. Então, com aquela boca de cantar, eu cantava pelos corredores da casa em que morava e cantava pelas ruas e cantava pelas cacimbas, tanto que terminei ficando meio conhecido como o menino que gostava de cantar... e as pessoas me pediam para cantar.

Isso de ser curioso e de achar que minhas ações podem ecoar de alguma forma para além de mim e do meu corpo ficou meio impregnado na minha educação informal e, para além de minha infância, fomentou minha prática como Promotor de Justiça na 4 a Promotoria da Infância e da Juventude de Rondonópolis, órgão do qual fui titular entre 2012 e 2017. Foi justamente desse locus privilegiado que se lançaram, tardiamente, minha curiosidade e minha inquietação quanto ao número de mortes ocorridas entre os jovens negros que por ali passaram em razão da autoria de atos infracionais; nasceu ali uma profunda rejeição (quem sabe até aqui pusilânime) a continuar cantarolando pela eternidade os mesmos versos e verdades 
apressadas ensinados nas cátedras, na mídia, nos botecos, nas mesas de jantar sobre a condição do negro no Brasil.

Lembro-me bem de quando era aluno da antiga Escola Técnica Amaral Raposo, em Imperatriz/MA, pela qual participei do desfile do dia 07 de Setembro, em 1988 e, apesar de não ser o aluno mais clarinho, eu fazia o papel de senhor de escravos, vestido a caráter ao lado da Princesa Isabel. Era a encenação da abolição da escravatura e eu puxava numa das mãos uma corda de aproximadamente dois metros que se atava, na outra extremidade, aos pulsos de Itamar, um rapaz de pele um pouco mais escura que a minha. Daquele jeito, subimos desfilando pela Avenida Dorgival Pinheiro de Sousa e descemos pela Avenida Getúlio Vargas e, finalmente, ao chegarmos em frente ao dispositivo de honra das autoridades, armado na Praça Brasil, a Princesa Isabel me tomou as cordas das mãos e as desatou dos pulsos de Itamar, enquanto eu fazia as vezes de enraivecido e depois de conformado com a cena.

De algum modo, o fenômeno da abolição da escravatura se projetava no meu aprendizado como ação benevolente de uma princesa branca e implicava que ao povo negro restava a coercitiva tarefa de ser grato pela líberdade, afinal, o não ser escravo já lhe deveria vestir muito bem. Logo, não ser escravo e não ser negro talvez fosse o móvel daquelas peles que se esforçavam para ser peles não negras.

Noutras linhas, já disse que fui uma criança curiosa, cheía de perguntas, cheía de achar que os atos ruins ou bons ecoam nos dias que se seguem, mas sobre essa condição do negro eu simplesmente fui assimilando tudo que me era apresentado em casa, na escola, na igreja, nas brincadeiras de roda, nas ruas

Neste ponto, calha trazer uma indagação sobre minha postura enquanto investigador social, decorrente de uma inquietação que se despertou em mím logo nas primeiras linhas de Nascimento, quando ele revela seu lugar em relação ao objeto por ele investigado:

[...] Não posso e não me interessa transcender a mim mesmo como habitualmente os cientistas sociais declaram supostamente fazer em relação às suas investigações. Quanto a mim, considero-me parte da matéria investigada. Somente da minha própria experiência e situação no grupo étnico-cultural a que pertenço, interagindo no contexto global da sociedade brasileira, é que posso surpreender a realidade que condiciona o meu ser e o define. Situação que me envolve qual um cinturão histórico de onde não 
posso escapar conscientemente sem praticar a mentira, a traição, ou a distorção da minha personalidade. ${ }^{1}$

E de mim, o que posso esperar? Posso eu, que falo com propriedade da temática do negro, ser branco? Sendo branco ou sendo negro, a hipocrisia ficou do outro lado da porta e, finalmente, importa dizer que meu sangue negro correu naqueles negros que foram meus avós e muitos outros ascendentes, ainda corre naqueles negros que são meus tios, naqueles negros que temiam que seus filhos fossem mais negros ainda, naqueles negros que faziam muitos bons senhores lá do meu Maranhão sentirem asco se os vissem logo cedo, naqueles negros que dormiam se achando brancos, naqueles negros que o tempo parecia torná-los mais negros ainda

Muitas frases sobre a condição do povo negro são largamente usadas naquela amostragem do Brasil, lá da pequena Buritirana do Maranhão, onde passei a maior parte de minha infância. Cresci ouvindo dizeres como "isso é coisa de negro", "é negro, mas um cabra bom", "só poderia ser negro mesmo", eu não gosto de preto", "rapaz, você tá com catinga de negro" etc. Melhor explorando minhas lembranças, percebo agora que essas assertivas vinham de pessoas não brancas.

Com o uso dessa terminologia - pessoas não brancas ou pessoas-de-cor, volto ao diálogo com Nascimento para destacar a norma metodológica utilizada por ele na definição do ser negro e, assim, entender minha condição e passar a refletir sobre os passos que dei rumo à condição do branco que há poucas manhãs eu parecia ser:

[...] Como norma metodológica a ser observada neste trabalho desejamos inicialmente recusar discutir as classificações comumente mantidas pelas ciências sociais quando tentam definir o negro no Brasil; estas definições designam os brasileiros ora por sua marca (aparência) ora por sua origem (raça e/ou etnia). Ocorre que nenhum cientista ou qualquer ciência, manipulando conceitos como fenótipo ou genótipo pode negar o fato concreto de que no Brasil a marca é determinada pelo fator étnico elou racial. Um brasileiro é designado preto, negro, moreno, mulato, crioulo, pardo, mestiço, cabra - ou qualquer outro eufemismo; e o que todo o mundo compreende imediatamente, sem possibilidade de dúvidas, é que se trata de um homem-de-cor, isto é, aquele assim chamado

\footnotetext{
${ }^{1}$ NASCIMENTO, Abdias do. O Genocídio do Negro Brasileiro: processo de um racismo mascarado; prefácio de Florestan Fernandes - Rio de Janeiro: Editora Paz e Terra, 2017, p. 47.
} 
descende de escravos africanos. Trata-se, portanto, de um negro, não importa a gradação da cor da sua pele. Não vamos perder tempo com distinções supérfluas. ${ }^{2}$

Portanto, com esse referencial teórico continuo a escrita, de forma que ser moreno claro ou escuro para mim passou a ser uma questão deveras supérflua. Descendente de Cã, cor da pele, condição de subalternizado, construção social cunhada pelo europeu para o termo negro, origem nordestina, fatores econômicos numa ou noutra fase da vida: eu sou negro e assim decidi dizê-lo.

As repetições de conceitos e preconceitos na sociedade acabam reforçando e garantindo as características identitárias do povo negro, mas essas repetições, sejam elas meramente descritivas, sejam elas performativas, podem perfeitamente ser questionadas, interrompidas e contestadas. Conforme Silva:

[...] É nessa interrupção que residem as possibilidades de instauração de identidades que não representem simplesmente a reprodução das relações de poder existentes. É essa possibilidade de interromper o processo de "recorte e colagem", de efetuar uma parada no processo de "citacionalidade" que caracteriza os atos performativos que reforçam as diferenças instauradas, que torna possível pensar na produção de novas e renovadas identídades. ${ }^{3}$

Nos meus primeiros anos escolares, a escravidão retratada nos livros de história das Escolas José Rios e Dom Pedro II era uma coisa meio romântica, meio reveladora de uma interação bem sucedida entre negros e brancos, pela sexualidade, pela política, pelo trabalho e pela cultura, dando origem à grande nação brasileira.

É costumeira e presente no Brasil a representação social de que as condições adversas de inclusão social do negro e a falta de superação do racismo são coisas do passado, que foram extirpadas concomitantemente com a promulgação da Lei Áurea.

Entretanto, com Abdias Nascimento, passei a compreender melhor esse fenômeno, quando pude desnudar as estratégias usadas pelas classes dominantes

\footnotetext{
2 Ibidem, p. 48.

${ }^{3}$ SILVA, T. T. da. (org.) Identidade e diferença: a perspectiva dos estudos culturais. Petrópolis: Vozes, $2000, \mathrm{p}$.
} 
para o branqueamento do povo brasileiro, as quais desmentem um mito criado e defendido na atualidade, segundo os quais haveria aqui uma relação na dinâmica da sociedade em "que pretos e brancos convivem harmoniosamente, desfrutando iguais oportunidades de existência, sem nenhuma interferência, nesse jogo de paridade social, das respectivas origens raciais ou étnicas" ${ }^{4}$. $\bigcirc$ autor traz à luz como expedientes utilizados largamente como estratégía de branqueamento da raça: a subjugação da mulher negra que sofria abuso e exploração sexual (e dava origem ao produto de sangue misto - mulato, moreno, pardo etc.), a miscigenação, e as políticas imigratórias racistas, além do embranquecimento da cultura africana.

As justificativas iniciais para o sequestro de africanos livres e sua subjugação lusitana, das mais absurdas às inconfessáveis, ditavam que o povo negro formava uma raça subumana, uma raça destinada à escravidão, cuja força de trabalho era necessária ao sistema produtivo de riquezas. Naturalmente, o número de homens era muito maior do que o de mulheres, uma proporção de cinco para uma, impedindo que elas tivessem um núcleo familiar estável e facilitando o abuso e a exploração sexual que se tornaram costume entre os senhores de escravos que as estupravam e, noutras vezes, mantinham prostitutas negras.

As consequências deletérias dessas práticas são vistas até hoje na sociedade, com as representações que existem sobre a mulher negra, mulher de avidez sexual destacada, desqualificada para trabalhos técnicos ou bem remunerados, de moral rebaixada:

[...] Nessa versão, há o reconhecimento geral do povo de que a raça negra foi prostituída, e prostituição de baixo preço. Já que a existência da mulata significa o "produto" do prévio estupro da mulher africana, a implícação está em que após a brutal violação, a mulata tornou-se só objeto de fornicação, enquanto a mulher negra continuou relegada à sua função original, ou seja, o trabalho compulsório. Exploração econômica e lucro definem, ainda outra vez, seu papel social. ${ }^{5}$

Não à toa, entre 2005 e 2015 a mortalidade entre mulheres negras aumentou 22\%, chegando à taxa de 5,2 mortes a cada 110 mil habitantes, acima da média nacional. No mesmo período, entre mulheres não negras, esse índice sofreu uma redução de 7,4\% (3,1 mortes a cada 100 mil habitantes), isto é, abaixo da média nacional. As mesmas discrepâncias são registradas em índices como acesso a

\footnotetext{
4 Ibidem, p. 41.

5 Ibidem, p. 75.
} 
emprego e renda, qualificação, sensação de segurança etc. deixando claro que no Brasil a "combinação entre desigualdade de gênero e racismo é extremamente perversa e configura variável fundamental para compreendermos a violência letal contra a mulher no país"6.

A miscigenação física entre os povos brancos, indígenas e negros, não foí decorrente do encontro natural de povos, sem subjugação e voltada, de fato, à formação de uma nação em que imperasse a partição de objetivos comuns, a igualdade, a justiça social e o respeito mútuo. No Brasil, ela surgiu e foì conduzida em decorrência dos interesses da classe dominante, inicialmente, como forma de exploração e abusos sobre o corpo da mulher negra e, ao depoís, como estratégía de embranquecimento da população, como forma de extirpar o atraso decorrente da mancha negra sobre o solo brasileiro:

Situado no meio do caminho entre a casa grande e a senzala, o mulato prestou serviços importantes à classe dominante; durante a escravidão ele foi capitão-de-mato, feitor, - usado noutras tarefas de confiança dos senhores, e, mais recentemente, o erigiram como um símbolo da nossa "democracia racial". Nele se concentraram as esperanças de conjurar a "ameaça racial" representada pelos africanos. E estabelecendo o tipo mulato como o primeiro degrau na escada da branquificação sistemática do povo brasileíro, ele é o marco que assinala o início da liquidação da raça negra no Brasil.

Porém, a despeito de qualquer vantagem de status social como ponte étnica destinada à salvação da raça ariana, a posição do mulato essencialmente se equivale àquela do negro: ambos vítimas de igual desprezo, idêntico preconceito e discriminação, cercado pelo mesmo desdém da sociedade brasileira institucionalmente branca. ${ }^{7}$

A política imigratória oficial, como disse, também foi uma estratégia utilizada para fazer desaparecer o povo negro no Brasil tornar a população mais bonita, de sangue mais puro, mais ariano. Tratou-se de política de Estado Republicano e não apenas um costume derivado do passado colonial e monárquico escravagista, isto é, a estratégia de impedir a imigração de negros para o Brasil foi objeto de várias

\footnotetext{
${ }^{6}$ Atlas da Violência 2017, produzido pelo Instituto de Pesquisa Econômica Aplicada (Ipea) em parceria com o Fórum Brasileiro de Segurança Pública (FBSP).
}

7 NASCIMENTO, op. cit., 2017, p. 69. 
discussões nos Poderes constituídos, das quais destaco um dos vários exemplos trazidos por Nascimento, o Decreto-Lei 7967, promulgado por Getúlio Vargas em 1945, o qual era voltado a preservar e desenvolver a composição étnica da nação, em respeito à sua ascendência europeia.

Eu cresci num Brasil em que aprendi a acreditar na vigência da democracia racial, ainda que em escolas alheias a qualquer indicador de qualidade do ensino, ensinaram-me assim e deixar o lugar que assumi nesse ardil é uma tarefa deveras cruenta, é difícil escrever sobre isso. Escola, família e sociedade lamberam meus ouvidos cuidadosamente, com o mesmo zelo dos beija-flores que salivam em teias de aranha pacientemente colhidas nas capoeiras e nos jardins para fazer seus ninhos.

Mas estou construindo uma nova mentalidade, apesar das intervenções do sistema educacional, dos meios de comunicação de massa e da produção literária a que tive acesso. A tristeza que, por vezes, fazia morada em mim, cedeu lugar a um outro choro, mais sofrido, mais paciente; nunca tive a sensação de ser o filho mais amado de minha pátria, nem mesmo quando estou desviando de pindobas nos morros e baixadas do meu Maranhão, ali aonde vejo que a dor nos babaçuais parece mais amena, aonde os corrupiões e os xexéus cantam sem medo de mim, porque medo em mim ali não há, porque o canto dos pássaros e o barulho do vento se expressam sem armadilhas.

Ao tratar da democracia racial brasileira, Nascimento se propõe a surpreender a realidade que 0 condiciona e 0 define, enquanto sujeito experimentado num grupo étnico-racial e, portanto, tem meu respeito, tanto quanto o vento e os pássaros que me ensinam sobre a verdade:

[.]. Monstruosa máquina ironicamente designada "democracia racial" que só concede aos negros um único "privilégio": aquele de se tornarem brancos, por dentro e por fora. A palavra-senha desse imperialismo da brancura, e do capitalismo que lhe é inerente, responde a apelidos bastardos como assimilação, aculturação, miscigenação; mas sabemos que embaixo da superfície teórica permanece intocada a crença na inferioridade do africano e seus descendentes. ${ }^{8}$

Tornarem-se brancos por dentro e por fora como único privilégio à disposição do negro, diante da propalada democracia racial brasileira, inclusive no que se refere aos usos e costumes que compunham a sua cultura. Foi assim com a

\footnotetext{
${ }^{8}$ NASCIMENTO, op. cit., 2017, p. 111.
} 
catequese compulsória promovida pela Igreja Católica e continua sendo assim com as violências persistentes contra os adeptos da religiosidade de matriz africana; foi assim quando os "benevolentes" dirigentes da Colônia permitiam aos negros os seus batuques, sua dança e seus cantos, na verdade, para forçar a perpetuação dos sentimentos de aversão e hostilidade mútuas entre as diversas nações africanas representadas entre os escravos" e continua sendo assim com um Estado pródigo na produção de leis de igualdade racial e não menos pródigo em descumpri-las:

Eis que agora, depois de algumas décadas, não sendo mais senhor de escravos (e não aceito a pecha de capitão do mato), quis o tempo que a corda que atava os pulsos de Itamar voltasse às minhas mãos. Com efeito, enquanto titular da Promotoria de Justiça da Infância e da Juventude de Rondonópolis, tornei-me responsável pelas ações socioeducativas em face dos adolescentes autores de atos infracionais e, em tal condição, testemunhei violações de direitos e o sofrimento de várias famílias de adolescentes pretos assassinados, como sói acontecer no resto do país

Com efeito, colhe-se do Mapa da violência 2013 que os homicídios são uma das principais causas de morte de jovens no Brasil, atingindo principalmente negros do sexo masculino, moradores das periferias e áreas metropolitanas dos centros urbanos:

[..] O número de homicídios de jovens brancos cai de 6.596 em 2002 , para 3.973 em 2011: queda de 39.8\%, bem maior que a do conjunto da população, que foi de $26,4 \%$

Já as vítimas negras entre os jovens cresceram de 11.321 para 13.405, isto é, um aumento de 24,1\%.

Assim, a participação dos jovens brancos no total de homicídios juvenis do país cai de 36,7\% em 2002, para 22,8\% em 2011. Por sua vez, a partícipação dos jovens negros, que já era muito elevada em 2002, 63\%, cresce ainda mais, indo para 76,9\%.

Com esse diferencial de ritmos, a vitimização de jovens negros passa de 71,6\% em 2002 - nesse ano morrem proporcionalmente $71,6 \%$ mais jovens negros que brancos - para 237,4\% em 2011, maior ainda que a pesada vitimização na população total, que nesse ano foi de $153,4 \%^{10}$

${ }^{9}$ NASCIMENTO, op. cit., 2017, p. 65.

10 WAISELFISZ, Julio Jacobo. Mapa da violência 2013: homicídios e juventude no Brasil. Rio de Janeiro: CEBELA, FLACSO, 2013, p. 89. 
Com a mesma desdita, a seletividade dos Homicídios por Armas de Fogo (HAF) é assim analisada no Mapa da Violência de 2016:

[..] Ainda mais perversa e preocupante é a seletividade racial dos HAF, além de sua tendência crescente. Entre 2003 e 2014, as taxas de HAF de brancos caem 27,1\%, de 14,5, em 2003, para 10,6, em 2014; enquanto a taxa de homicídios de negros aumenta 9,9\%: de 24,9 para 27,4 Com esse diferencial, a vitimização negra do país, que em 2003 era de 71,7\%, em poucos anos mais que duplica: em 2014, já é de $158,9 \%$, ou seja, morrem 2,6 vezes mais negros que brancos vitimados por arma de fogo

Além da herança do passado colonial e escravocrata, outros fatores podem ser mencionados na tentativa de explicar essa crescente seletividade racial da violência homicida. Em primeiro lugar, a progressiva privatização do aparelho de segurança. Como tem acontecido com outros serviços públicos, como a saúde, a educação e. mais recentemente, a Previdência Social, o Estado vai, progressivamente, se limitar a oferecer, para o conjunto da população, um mínimo - e muitas vezes nem isso - de acesso aos serviços e benefícios sociais considerados básicos. Para os setores com condições financeiras, estruturam-se serviços privados de qualidade adequada. Com a segurança vem ocorrendo esse mesmo processo, de forma acelerada, nos últimos anos: quem tem condições econômicas, paga um serviço privado. E a pesquisa domiciliar do IBGE, de 2011, é clara ao delinear quem pode e quem não pode ter acesso a esses serviços: as famílias negras tinham uma renda média de $R \$ 1.978,30$, em valores de 2011, e as brancas, de $R$ \$ 3.465,30, isto é, $75,2 \%$ a mais. Em teoria, os setores e áreas mais abastados, geralmente brancos, têm uma dupla segurança: a pública e a privada; enquanto as menos abastadas, a das periferias, predominantemente negros, têm de se contentar com o mínimo de segurança que o Estado oferece.

Um segundo fator adiciona-se e complementa o anterior: a segurança, a saúde, a educação, etc, áreas que formam parte do jogo político-eleitoral e da disputa partidária. Âs ações e a cobertura da segurança pública distribuem-se de forma inteiramente desigual nas diversas áreas geográficas, priorizando espaços segundo sua visibilidade política, seu impacto na opinião pública e, principalmente, na mídia, que reage de forma bem diferenciada de acordo com o status social e econômico das vítimas. Como resultado, os recursos públicos de proteção são canalizados, 
preferentemente, para as áreas mais abastadas, com predominância de população branca, que ostentam os benefícios de dupla segurança, pública e privada; enquanto as áreas periféricas, de composição majoritariamente negra, não são atendidas por nenhuma das duas. ${ }^{11}$

Portanto, ao lado da herança do passado colonial e escravocrata, outros dois fatores são utilizados para explicar a crescente seletividade racial da violência homicida, quais sejam, a progressiva privatização do aparelho de segurança (o mesmo ocorre com saúde, educação e, mais recentemente, Previdência Social) e a seletividade político-eleitoreira para oferecimento de serviços básicos à população.

Quem bem traduz o sentido dessa violência é Žižek ${ }^{12}$, chamando-a de violência sistêmica, isto é, aquela que nasce dos efeitos catastróficos dos sistemas políticos e econômicos que se fundamentam na injustiça e nas desigualdades perfeitamente visíveis na sociedade brasileira que durante séculos estigmatizou a maior parte da população, principalmente das regiões mais empobrecidas.

Sob tal perspectiva, passo a refletir sobre uma experiência realizada aqui na cidade de Rondonópolis com adolescentes egressos do Sistema Socioeducativo.

Como aparenta ser quase um testemunho, sinto-me na obrigação de fazer uma advertência; não raro, nas lides judiciais, na rotina forense, desconfia-se daquele declarante muito prestativo e detalhista, cujo relato é incrivelmente preciso e sem paixões. Dos vários anos à frente da Promotoria de Justiça da Infância e da Juventude, posso dizer que trago muitas lembranças, nem sempre precisas, eis que atravessadas pela dor de mães que se viram com seus filhos assassinados ou presos, nem sempre imparciais, eis que constituídas no vigor de uma batalha nem sempre justa, nem sempre ladeada pela igualdade de armas. Portanto, não prometo precisão nem imparcialidade nos meus relatos e nas respectivas análises, mas prometo sinceridade, muito embora entenda a dimensão do preço dela, consoante destacava Nietzsche, em seus Escritos sobre Direito:

[..] Alguém tinha a mal hábito de se explicar muito sinceramente, quando era o caso, sobre os motivos que o levaram a agir e que

11 WAISELFISZ, Julio Jacobo. Mapa da violência 2016: homicídios por armas de fogo no Brasil. Rio de Janeiro: CEBELA, FLACSO, 2015, p. 72-73.

12 ŽIŽEK, Slavoj.Violência: seis reflexões laterais. Tradução de Miguel Serras Pereira. São Paulo: Boitempo, 2014, p. 18. 
eram tão bons e maus quanto são os motivos de todos os homens. Primeiro ele causou escândalo, depois suscitou a desconfiança, depois foi decididamente apontado como perigoso e em seguida banido da sociedade, até que finalmente a justiça se lembrou, nesta ou naquela circunstância, de um ser tão rejeitado, para quem ela antigamente não tinha olhos, ou pelo menos tinha os olhos fechados. Esta falta de discrição quanto ao segredo geral e esta tendência imperdoável de ver o que ninguém queria ver [a si mesmo] levaram-no à prisão e a uma morte prematura. ${ }^{13}$

Era fevereiro de 2015 e, numa dessas lagoas de águas barrentas, na Rodovia do Peixe, lá no meío da paisagem degradada, da pastagem seca, apareceu boiando mais um corpo. Ele tinha a cor da democracia racial brasileira e seus lábios eram largos, deixando pistas de como ficou conhecida, em vida, aquela extensa lista de delítos. Eu o conhecia, não conhecia muito bem, mas conhecia um pouco.

\author{
Não é só um batuque ao longe? \\ Quem é quem nessa dança? \\ Quem é quem nessa trança? \\ Donde vem essa dança? \\ Qual a cor dessa trança?
}

Era agosto de 2016 e, e depois de dois tíros, veio um grito que dizia: "safado morre assim". Lá estava mais um corpo jovem e negro estendido no chão, ainda vivo, vivo o suficiente para ouvir mais algumas injúrias e receber mais alguns disparos na cara. Claro, a imprensa destacou sutilmente que, enquanto xingavam e atiravam enlouquecidamente, os assassinos ouviam funk. Eu o conhecia, não conhecia muito bem, mas conhecia um pouco.

\author{
Bandido negro é bandido morto? \\ Bandido bom é bandido morto? \\ Morto bandido é negro? \\ Corpo negro é bandido? \\ Bandido negro é morto?
}

${ }^{13}$ NIETZSCHE, Friedrich Wilhelm. Escritos sobre direito. Tradução, apresentação e notas: Noéli Correia de Melo Sobrinho - Rio de Janeiro: PUC-Rio - São Paulo: Ed. Loyola, 2009, p. 167. 
Desde 2012, dos adolescentes que sofreram medida socioeducativa de internação no Centro Socioeducativo de Rondonópolis, na imensa maioria negros, pelo menos quarenta (40) foram assassinados depois de terem suas medidas progredidas para o meio aberto ${ }^{14}$, isto é, terem suas medidas de internação substituídas por liberdade assistida. $\bigcirc$ problema é justamente esse, em liberdade assistidos com que educação, com que saúde, com que lazer, com que segurança, com que promoção de qualificação, emprego e renda?

Diante desse quadro e para melhor entender o modo pelo qual age parte da sociedade quanto aos adolescentes egressos do Sistema Socioeducativo, cumpre fazer um breve relato sobre o "Projeto Educação Para a Liberdade", criado pelo Ministério Público do Estado de Mato Grosso - MPE, através da Promotoria de Justiça da Infância e Juventude de Rondonópolis em parceria com o Programa de Pós-Graduação em Educação - PPGEdu, da Universidade Federal de Mato Grosso Campus Universitário de Rondonópolis, Secretaria de Promoção e Assistência Social e com a Obra Kolping Mato Grosso.

objetivo desse projeto foi qualificar e, ulteriormente, inserir no mercado de trabalho adolescentes que estavam em situação de extrema vulnerabilidade em razão da baixa escolaridade $\bigcirc$ nome escolhido para o projeto foi "Educação para a Liberdade", porque seus idealizadores acreditaram na capacidade da educação em transformar a realidade política, econômica e social das pessoas, possibilitando que elas saiam das situações de vulnerabilidade.

Orçado em pouco mais de $\mathrm{R} \$ 60$ mil, o projeto foi custeado pelo Ministério Público do Trabalho - MPT 23a Região, por meio de multas aplicadas a empresas no combate a irregularidades trabalhistas. Os alunos receberam o curso gratuito de Auxiliar de Logística administrado pela ONG Obra Kolping Mato Grosso, com sede em Rondonópolis, além de oficinas de formação humana, cultural e artística ofertadas por professores e alunos da UFMT de diversas áreas do conhecimento.

No decorrer desse exercício de cidadania, finalizado em setembro de 2017. três turmas foram atendidas. A primeira foi composta por adolescentes em conflito com a lei, que cumpriam medida socioeducativa em meio fechado e aberto, a segunda foì composta por adolescentes que não tinham passagens pelo socioeducativo e a terceira foi composta por jovens do sexo feminino, de bairros

\footnotetext{
14 Informações colhidas na $4^{\text {a }}$ Promotoria de Justiça Cível de Rondonópolis/MT que atua na defesa da Infância e da Juventude.
} 
periféricos de Rondonópolis, que se qualificaram em excelência no atendimento e técnicas de venda.

Todas as turmas tiveram a mesma metodologia de trabalho, mas apresentaram resultados distintos. No primeiro caso, na turma dos adolescentes em conflito com a lei, a evasão foi bem maior e diversos fatores podem ser relacionados, tais como maior indisciplina dos alunos, fragilidades no acompanhamento pelas famílias, falta de apoio do Poder Público no que se refere ao concomitante oferecimento de tratamento contra o uso de drogas etc.

Destaque-se, entretanto, um traço comum às três turmas: a grande dificuldade de encontrar postos de trabalho para inserção dos adolescentes qualificados no Projeto, apesar dos esforços das instituições parceiras. Com efeito, dos adolescentes de ambos os sexos formados, o número deles inserido no mercado de trabalho foi desestimulante, apenas um, o que me conduz à assertiva de Tella, para quem, mesmo após o fim do sistema escravocrata, no Brasil e em Portugal, ainda são desenvolvidas estratégias de controle social e de manutenção das relações de poder político e econômico, baseadas na preterição dos africanos, negros portugueses e brasileiros:

[.]. Os estigmas associados à cor da pele e ao local onde moram tornam evidente que tais construções sociais servem para desqualificar e inferiorizar pessoas e grupos dominados. As referências estigmatizadas produzidas e reproduzidas por setores sociais, historicamente, estabelecem um tipo de relação conflituosa de poderes desequilibrados entre os que moram em locais degradados e periféricos e os grupos dominantes.

As sociedades brasileira e portuguesa se caracterizam pela histórica presença da cultura e dos descendentes de africanos. Não há como contar a história desses países sem deixar de passar pela África ou pela contribuição que deram para a construção de ambas as sociedades. Mas, também não devemos deixar de destacar que as relações de poder entre os negros, apresentados aqui como grupo dominado, e os grupos dominantes destas duas sociedades, sempre aconteceram de forma absolutamente desequilibrada. $\bigcirc$ objetivo dos grupos dominantes nunca foi a exclusão destes grupos - os grupos dominantes sempre necessitaram que os dominados fizessem parte do sistema social -, mas o controle 
social, por meio dos restritos acessos ao poder político e econômico por eles já ocupados. ${ }^{15}$

Sobre essa primeira turma, cabe destaque para o fato de que, bem no seu início, houve ampla divulgação do projeto, em todas as mídias, foram realizadas reuniões, inclusive, com sindicatos e associações de potenciais empregadores (Poder Público, Associação Comercial, Sindicato dos Transportadores de Cargas etc.), de forma que o Projeto "Educação para a Líberdade" ficou conhecido como aquele que iria dar guarida aos adolescentes egressos do sistema socioeducativo

Na rotina dos órgãos de apoío da Justiça da Infância e Juventude, observa-se que os adolescentes que ocupam as vagas de trabalho aprendiz são aqueles com vida escolar e familiar estáveis ou que se submeteram longânimes e inauditos às péssimas condições das escolas públicas em que estudam. Seja como for, a escolaridade exigida e os arranjos para acessar as vagas de emprego não abraçam a realidade dos jovens subalternizados ou marcados pela pecha de infratores.

Essa face cruel da violência institucional, sobrelevada em relação aos jovens egressos do sistema socioeducativo, em sua maioria negros, vem se perpetuando ao longo dos séculos e volto a Nascimento para explicar:

[...] Depois de sete anos de trabalho, o velho, o doente, o aleijado e o mutilado - aqueles que sobreviveram aos horrores da escravidão e não podiam continuar mantendo satisfatória capacidade produtiva - eram atirados à rua, à própria sorte, qual lixo humano indesejável; estes eram chamados de "africanos livres". Não passava, a liberdade sob tais condições, de pura e simples forma de legalizado assassínio coletivo. As classes dirigentes e autoridades públicas praticavam a líbertação dos escravos idosos, dos inválidos e dos enfermos incuráveis, sem lhes conceder qualquer recurso, apoio, ou meio de subsistência. Em 1888 se repetíia o mesmo ato 'líberador' que a História do Brasil registra com o nome de Abolição ou de Lei Áurea, aquillo que não passou de um assassinato em massa, ou seja, multiplicação do crime, em menor escala, dos africanos livres. Atirando os africanos e seus descendentes para fora da sociedade, a abolição exonerou de responsabilidades os senhores, o estado e a Igreja. Tudo cessou, extinguitu-se todo o humanismo, qualquer gesto de solidariedade ou de justiça social: o

15 TELLA, Marco Aurélio. Estigmas e desqualificação social dos negros em São Paulo e Lisboa. Ponto-evírgula, 3: 152-169, 2008, p. 167. 
africano e seus descendentes que sobrevivessem como pudessem. $^{16}$

Em última instância, não falta razão a quem diga que os adolescentes negros egressos do Centro Socioeducativo em Rondonópolis estão submetidos a dois sistemas do aparato de segurança, ambos eficientes somente quanto aos objetivos inconfessáveis do Estado:

- o primeiro é aquele sobremodo ideal e que não funciona, previsto no Estatuto da Criança e do Adolescente em que os atos infracionais, instruídos sob segredo de justiça, deveriam implicar o Estado, a sociedade e a família na aplicação das medidas socioeducativas ali previstas:

- o segundo, regido pela violência sistêmica, o que de fato existe, mas é ignorado por grande parcela das pessoas, impõe sanções privativas de liberdade em ambiente insalubre e desumano e aplica diuturnamente penalidades restritivas de direitos à juventude brasileira, notadamente, aos negros.

Na mesma toada e para melhor entender o fenômeno da punição pela restrição de direitos legítimos, colho as impressões de Foucault sobre o exercício do poder de punir pelo Estado:

[.]. Mas, de modo geral, as práticas punitivas se tornaram pudicas. Não tocar mais no corpo, ou o mínimo possível, e para atingir nele algo que não é o corpo propriamente (...). O sofrimento físico, a dor do corpo não são mais os elementos constitutivos da pena. $\bigcirc$ castigo passou de uma arte das sensações insuportáveís a uma economia dos direitos suspensos (...). Utopia do pudor judiciário: tirar a vida evitando de deixar que o condenado sinta o mal, privar de todos os direitos sem fazer sofrer, impor penas isentas de dor. ${ }^{17}$

○ Brasil é um país de terríveis contradições. Aqui, o caráter preventivorepressivo da punição, por vezes, não faz qualquer sentido, pois as penas já são aplicadas por antecipação a boa parte da população jovem negra, notadamente, as

${ }^{16}$ NASCIMENTO, op. cit., p. 65.

17 FOUCAULT, Michel. Vigiar e punir: nascimento da prisão; tradução de Raquel Ramalhete. Petrópolis: Vozes, 1987, p. 16-17. 
penas que implicam na limitação do exercício de direitos legítimos, tais como saúde, convivência familiar e comunitária, assistência social, educação de qualidade, profissionalização, emprego e renda, lazer etc

Eis aí um desafio que a sociedade precisa reconhecer que existe, entender que não se trata de "coisa de preto de movimentos sociais" ou de "defensores de delinquentes juvenis". A questão é se a elite econômica dominante, formada na maioria por pessoas que se declaram brancas, interessa-se por algo assim, isto é, assegurar a essa importante parcela da juventude brasileira sua existência digna e maneiras de inserção na economia do Estado que, aliás, foi fundado com o suor e o sangue de seus ascendentes.

É um problema que precisa ser superado, mas não é encarado às claras e, no dizer de Trindade, ".. não se trata de propor imediatismos para extirpar as diferenças sociais, mas sim de urgência para pôr termo às práticas de extermínio do diferente"18

Já, agora, pelo meio do caminho, tentando resistir ao outono, entre os vários questionamentos solitários e sem eco que faço, eu quero saber o que vai acontecer comigo depois que vi tantas mortes e, na falta de alguém que me leve a sério, na falta de alguém que não se incomode depois de ler as primeiras linhas daquilo que denuncio, acredito que meus últimos passos, minhas derradeiras ações permanecerão como um pêndulo, repetindo-se eternamente. Então, com esta boca de cantar, eu canto, mas as pessoas não me pedem para cantar.

18 TRINDADE, Judite Maria Barboza. Metamorfose: de criança para menor. 1998, 257 F. Dissertação (Tese de Doutorado) - Departamento de História da Universidade Federal do Paraná - Curitiba, p. 243. 